\title{
Pemanfaatan Youtube Sebagai Bahan Ajar Berbicara Bagi Pembelajar BIPA
}

\author{
Rae Dadela ${ }^{1 *}$, Deanty Rumandang Bulan ${ }^{2)}$, Dani Hermawan ${ }^{3)}$ \\ diajengrae@gmail.com ${ }^{1)}$, deantyrbulan@gmail.com ${ }^{2)}$, danihermawan922@gmail.com ${ }^{3)}$ \\ Universitas Bale Bandung, Indonesia, Jawa Barat
}

\begin{abstract}
Abstrak. Keberadaan youtube saat ini telah memberikan perubahan yang signifikan. Salah satunya dalam pembelajaran BIPA. Youtube dapat dimanfaatkan sebagai bahan ajar. Rumusan masalah dalam penelitian ini adalah bagaimanakah aspek bahasa dan tuturan youtuber food vlogger, Ria SW dalam menginformasikan suatu hal berdasarkan aspek kebudayaan lokal dalam 15 video yang tersaji dalam kanal youtube miliknya; bagaimanakah penyusunan bahan ajar berbicara Bahasa Indonesia bagi Penutur Asing yang bermuatan kebudayaan lokal; bagaimanakah efektivitas penggunaan bahan ajar Bahasa Indonesia bermuatan kebudayaan daerah. Metode yang digunakan dalam penelitian ini adalah studi deskriptif kualitatif. Penelitian ini dilakukan untuk mengetahui nilai variabel mandiri, baik dari satu variabel maupun lebih (independent) tanpa membuat perbandingan, atau menghubungkan dengan variabel lain dengan data yang berbentuk kata, skema, atau gambar. Hasil analisis dalam penelitian ini diperoleh sebanyak 102 data penggunaan kosakata tidak baku, 117 kosakata penamaan, dan 68 tuturan khusus youtuber Ria SW. Selanjutnya hasil uji kelayakan bahan ajar melalui angket yang disebarkan kepada beberapa pengajar BIPA diperoleh hasil bahwa bahan ajar tersebut layak untuk digunakan. Hal ini ditunjukkan dari hasil angket diperoleh rata-rata $73 \%$ para pengajar menyatakan sangat setuju. Adapun harapan dari penelitian ini adalah para pengajar dapat memanfaatkan bahan ajar tersebut dalam pembelajaran.
\end{abstract}

Kata kunci: bahan ajar, berbicara, BIPA, youtube

\section{Pendahuluan}

Bahasa Indonesia saat ini memegang peranan penting dalam kedudukannya sebagai bahasa asing. Dalam Undang-Undang RI No.24 Tahun 2009 Pasal 2 disebutkan "Pemerintah meningkatkan fungsi Bahasa Indonesia menjadi bahasa internasional secara bertahap, sistematis, dan berkelanjutan”. UU RI No. 24 di atas menunjukkan bahwa Pemerintah Indonesia memiliki keseriusan untuk menjadikan bahasa Indonesia sebagai bahasa internasional. Hal ini dibuktikan dengan peran Badan Pembinaan dan Pengembangan Bahasa Kementerian Pendidikan dan Kebudayaan yang terus mendorong berkembangnya program Bahasa Indonesia untuk Penutur Asing (BIPA).

Pembelajar bahasa asing mempelajari Bahasa Indonesia bertujuan untuk akademis dan praktis. Tujuan bersifat akademis diarahkan untuk peningkatan penguasaan bahasa, sedangkan tujuan bersifat praktis berkenaan dengan keperluan pamrih, yaitu berkenaan dengan kuliah, mengenal budaya, penelitian, dan keperluan kerja.

Menurut Siroj (2015), selama ini besarnya minat penutur asing untuk mempelajari bahasa Indonesia tidak didampingi dengan bahan ajar yang selaras dengan keinginan penutur asing dalam mempelajari bahasa Indonesia.

Saat ini youtube merupakan salah satu situs website yang paling banyak digemari masyarakat. Hal ini menjadi pemicu para penyaji konten youtube -sering disebut youtuber- untuk berlomba-lomba menyajikan video yang diminati masyarakat. Tidak sedikit para youtuber mengambil topik tentang video unboxing, video tutorial, bahkan sampai video informasi kuliner. 
Konten yang menyajikan info tentang reviu makanan, lokasi kuliner terfavorit hingga restoran terbaru yang banyak diburu oleh penikmat youtube.

Konten video yang disajikan selain bertujuan untuk menarik sebanyak mungkin subscribe dari pengguna juga mengedukasi masyarakat. Dalam konten video kuliner, youtuber sengaja ingin menyampaikan informasi kepada pengguna tentang tempat yang menyajikan makanan khas daerah. Seperti halnya youtuber Ria SW. Channel videonya kebanyakan memaparkan tentang kuliner khas daerah yang belum banyak diketahui masyarakat. Dengan cara penyajiannya dan penggunaan kosakata yang khas menjadi daya tarik bagi penikmat youtube bahkan penasaran ingin datang langsung untuk sekadar mencicipi makanan yang sedang di-review-nya. Kosakata khas inilah yang menjadi daya tarik peneliti untuk melakukan penelitian. Diharapkan melalui video tersebut dapat membantu para pembelajar Bahasa Indonesia untuk penutur asing memahami dan mampu menggunakan kosakata Bahasa Indonesia melalui kebudayaan daerah.

Mengenal kehidupan budaya sama halnya dengan mempelajari bahasanya. Hal ini sejalan dengan pendapat Chaer (2009) mengatakan bahwa berbahasa adalah penyampaian pikiran dan perasaan dari orang yang berbicara mengenai masalah yang dihadapi dalam kehidupan budayanya. Maka kehidupan manusia tidak terlepas dari berbahasa, berpikir, dan berbudaya. Hal ini yang menjadi dasar dalam kegiatan penelitian ini. Peneliti beranggapan perlu adanya bahan ajar yang dapat digunakan oleh pemelajar BIPA. Keterbatasan akan bahan ajar BIPA di toko-toko buku menjadi alasan kami perlu melakukan penelitian. Bahan ajar yang akan disusun diambil dari hasil analisis tuturan youtuber Ria SW yang meliputi aspek bahasa, kebahasaan, dan lintas budaya dalam video di channel Youtube miliknya.

Urgensi penelitian ini menitikberatkan pada penyusunan bahan ajar berbicara BIPA. Bahan ajar akan disusun dengan muatan kebudayaan daerah. Bahan ajar yang disusun akan memberikan gambaran bagi penutur asing terhadap kondisi lingkungan, sosial, budaya, dan adat istiadat bangsa Indonesia sehari-hari, sehingga akan mengantarkan penutur asing lebih tertarik dan cepat dalam belajar bahasa Indonesia sebagai bahasa asing.

Berdasarkan penelitian yang dilakukan oleh Adji (2017), disebutkan bahwa mahasiswa asing pembelajar BIPA menaruh minat yang tinggi pada budaya sehari-hari yang tampak. Hal ini dianggap menarik karena berkolerasi dengan kebutuhan mahasiswa asing untuk beradaptasi langsung dengan masyarakat lokal. Selain itu, makanan disebut sebagai bagian budaya yang menarik minat pembelajar BIPA karena merupakan artefak budaya yang paling sering ditemui sehari-hari.

Penelitian lainnya yang telah dilakukan oleh Mujianto (2019), disebutkan bahwa pemanfaatan youtube sebagai media ajar berperan secara signifikan terhadap motivasi belajar mahasiswa. Berdasarkan permalasahan di atas peneliti melakukan penelitian melalui judul "Pemanfaatan Youtube sebagai Bahan Ajar Berbicara untuk Pembelajar BIPA".

\section{Metode}

Metode yang digunakan dalam penelitian ini adalah studi deskriptif kualitatif, yakni penelitian yang dilakukan untuk mengetahui nilai variabel mandiri, baik dari satu variabel maupun lebih (independent) tanpa membuat perbandingan, atau menghubungkan dengan variabel lain dengan data yang berbentuk kata, skema, atau gambar (Sugiyono, 2013). Objek penelitian ini 
adalah video youtube di chanel Ria SW yang bertemakan makanan khas dari berbagai daerah di Indonesia. Penentuan sampel diambil berdasarkan teori Arikunto (2006), yakni "apabila kurang dari 100 lebih baik diambil semua hingga penelitiannya merupakan penelitian populasi. Jika subjeknya besar dapat diambil 10-15\% atau $20-55 \%$ ". Jumlah populasi penelitian sebanyak 122 video. Adapun sampel penelitian sebanyak 122 video. Adapun sampel penelitian berjumlah 15 video atau sekitar $18 \%$ dari total populasi. Pengerjaan tugas dilaksanakan secara bersama-sama oleh ketua dan anggota dengan waktu kerja 8 jam/minggu.

Pengumpulan data diawali dengan cara mengunduh video-video yang bertemakan makanan khas daerah di Indonesia di kanal Ria SW. Video-video tersebut lalu dibuat transkripsi untuk memudahkan proses analisis dengan cara memilih dan mendeskripsikan aspek-aspek tuturan bahasa dan unsur kebudayaan masing-masing daerah. Hasil analisis video tersebut selanjutnya akan digunakan untuk penyusunan bahan ajar berbicara BIPA dengan berbasis aspek budaya meliputi bahasa dan artefak budaya sehari-hari (kebiasaan lokal dan makanan).

\section{Analisis dan Pembahasan}

Analisis data penelitian ini difokuskan pada tiga aspek, yakni aspek bahasa, kebahasaan, dan lintas budaya. Penggunaan Bahasa Indonesia yang disampaikan oleh Ria SW terdapat beberapa kata-kata unik yang menjadi ciri khas tuturannya. Terdapat 15 judul channel yang kami teliti yaitu:

1) Data 1: Bali Night Market\#4

2) Data 2: Delicious Food in Denpasar\#2

3) Data 3: Jajanan Semarang \#02

4) Data 4: Jakarta Night Market

5) Data 5: Makanan Legendaris Malang\#2

6) Data 6: Makanan Legendaris Semarang\#3

7) Data 7: Makanan Legendaris Solo \#2

8) Data 8: Makanan Pedas Solo\#03

9) Data 9: Menggila di Blok M

10) Data 10: Menggila di Jogja

11) Data 11: Menggila di Malang\#01

12) Data 12: Menggila di Semarang\#1

13) Data 13: Menggila di Solo \#01

14) Data 14: Solo Night Market \#4

15) Data 15: Super-super Yummy Food in Kuta

Beberapa temuan menarik yang menjadi kekhasan youtuber Ria SW akan disajikan dalam tabel berikut.

Tabel 1

Hasil Analisis Bahasa dan Tuturan Data 1

\begin{tabular}{ll}
\hline Aspek & Keterangan \\
\hline Bahasa & Ragam tidak baku: \\
& rasain, kalo, emang, ngeliat. \\
& Seharusnya: \\
& merasakan, kalau, memang, melihat \\
\hline
\end{tabular}




\section{Kosa kata penamaan:}

kue pukis, bubuh bali, pisang molen, pisang rai, nasi campur, babi guling, gado-gado, sate kambing, gule kambing, sate madura, nasi jingo, nasi jingo ayam, soto sapi.

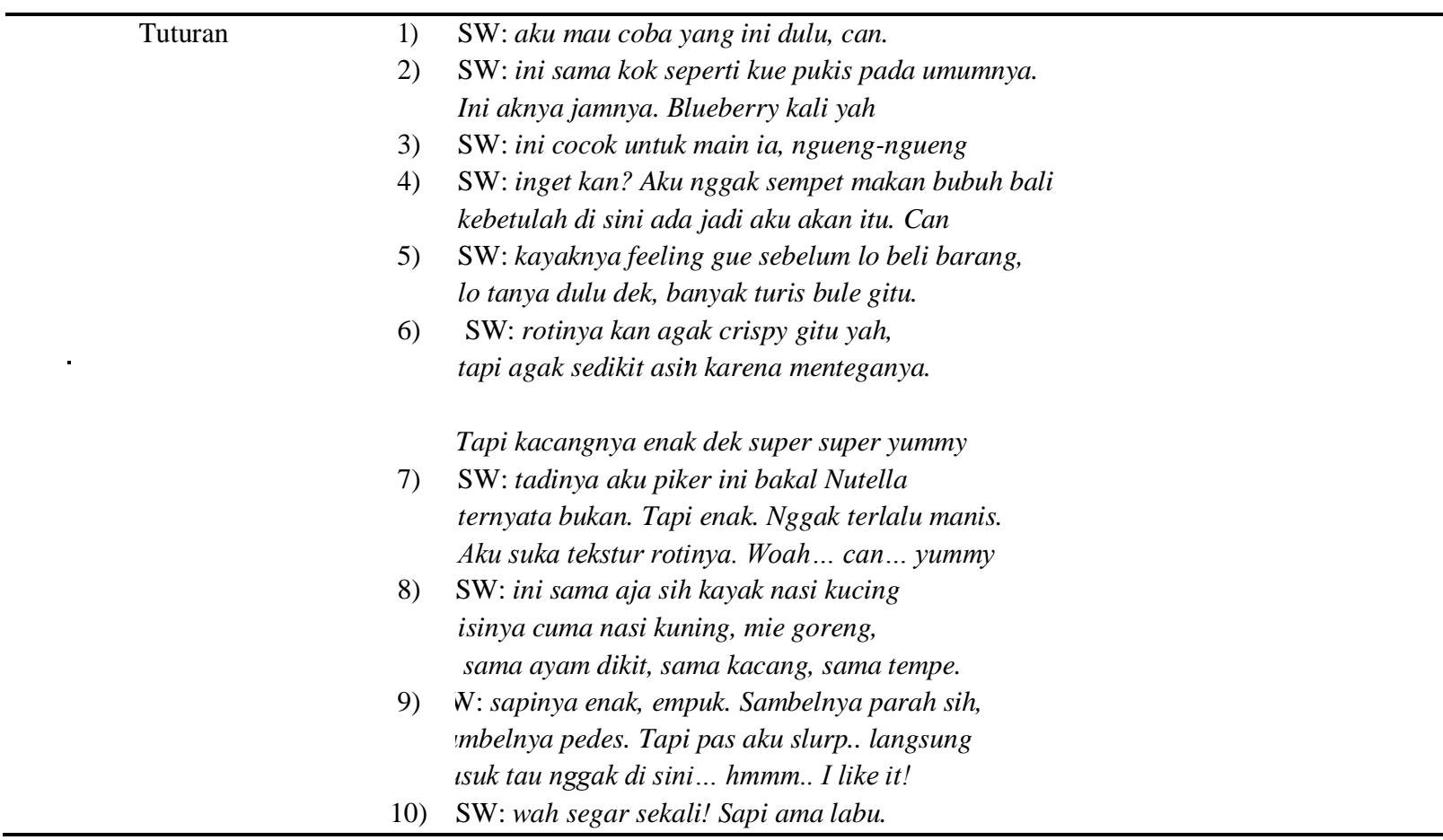

Pada data 1 terdapat 4 ragam tidak formal/tidak baku, 14 kosakata penamaan. Cara penuturan SW (untuk kata ganti Ria SW) kebanyakan menyajikan dan menjelaskan suatu makanan khas daerah dengan menggunakan kosakata penamaan. Ekspresi dan pilihan kata yang khas dari penutur seperti yang tersaji dalam data di atas memberikan kesan persuasif kepada penyimak. Hal tersebut bisa dilihat pada data [1.2], [1.6], [1.7], [1.8], [1.9], [1.10].

Makanan khas yang dideskripsikan oleh SW tersebut merupakan makanan khas Bali. Mungkin di beberapa daerah terdapat juga makanan yang diolah dan disajikan sama tapi dengan penamaan yang berbeda. Proses penamaan tersebut tentunya bergantung pada budaya masingmasing daerah. Di Indonesia setiap daerah memiliki Bahasa dan budaya yang berbeda.

\section{Tabel 2}

Hasil Analisis Bahasa dan Tuturan Data 2

\begin{tabular}{ll}
\hline Aspek & Ragam tidak baku: \\
\hline Bahasa & dibilang, bikin, liatin, deket, abis,makasih, saos, pake \\
& Ragam bakunya: \\
& Dikatakan, membuat, memperlihatkan, dekat, habis, terima kasih, saus, pakai, \\
& Kosa kata penamaan: \\
& bubuh bali (bubur khas bali), tipat, es sirsak, nasi campur, sate bali, sambal bali, betutu,
\end{tabular}


1) SW: Selamat makan, bubuhnya itu diganti sama tipat. Tapi tetap sama makanan tradisional Bali. Jadi bedanya sama bubur kita yang biasa itu, kita biasanya pake ayam, cakwe, kacang terus pake kaldu gitu ya. Kalo dia tuh pake sayuran.

2) SW: pedesnya segar sekali... hmmm.. I like it

3) SW: ini isinya ada kacang Panjang, tauge, ceker, telur, suwiran ayam

4) SW: selamat makan, nih aku pesen yang nasi campur satu (nasi, telur, ayam suwie, udang, sate tusuk dan sate lilit, sayur, sambal. Nasi campur tiga yang komplit banget. Ini kurang balado dan rendang.

5) SW: biasanya kalo kita makan sate bumbunya itu kan saos kacang atau saos kecap kan? Kalo ini tuh dia pake sambel khas Bali. Hah? Sambal khas Bali? Sambal khas Bali apaan?

6) SW: sambalnya itu diracik sama bawang putih dicampur sama kemiri dan terasi, abis itu disiram pake minyak sama jeruk limau.

7) SW: dia ini kuahnya pake kuah betutu. Aku mau coba, mm... sambalnya

Data kedua menyajikan video kuliner daerah Denpasar. Ragam bahasa yang digunakan oleh penutur yaitu ragam nonformal. Terdapat 8 kosakata tidak baku, 8 kosakata penamaan, dan 7 tuturan khas SW yang digunakan. Makanan khas yang disajikan oleh SW berasal dari daerah Denpasar. Terdapat 7 makanan khas Bali.

Kekhasan SW pada saat menjelaskan dan mendeskripsikan makanan khas Denpasar terdapat pada data [2.1], [2.4], [2.5], [2.6]. SW memberikan penjelasan tentang makanan tersebut dengan kalimat yang sangat persuasif. Informasi yang disampaikan sangat memberikan kesan informatif. Penyimak seolah-olah untuk sama-sama membayangkan dan merasakan berada di daerah yang dimaksud SW. Hal tersebut tentunya karena kemampuan mengolah kalimat yang dibuat SW yang bisa menghipnotis penyimak.

Tabel 3

Hasil Analisis Bahasa dan Tuturan Data 3

\begin{tabular}{ll}
\hline Aspek & Ragam tidak baku: \\
Bahasa & Kgantuk, udah, secuprit \\
& Ragam bakunya: \\
& Mengantuk, sudah, sedikit, \\
& Kosa kata penamaan: \\
& Nasi kucing, otak-otak, sambal terasi, sambal merah, lekker paimo, \\
& SW: Oh ya (nasi kucing ayam balado) ayamnya disini. 2018 itu anti mainstream. Sendok dan \\
& sendok. Ayamnya secuprit banget. \\
& SW: yah namanya juga nasi kucing, porsi kucing \\
& SW: (Nasi kucing ikan teri) terinya juga dikit sih. Segitu doang. Coba deh! Can! Nggak terlalu \\
& $\begin{array}{l}\text { asin yah (terinya). Can! Yummy... aku suka ikan terinya. Ini aku nggak ngerti ini apa. Kayak } \\
\text { bakwan kali yah? Kayak gini-gini nggak boleh ditinggalin gitu aja. }\end{array}$
\end{tabular}


SW: Kita mulai dengan salad biar ada sayurnya. Kalo daging dari Torikarage kasih sedikit sambal terasi dan sambel matah. Ambil sayur kailannya agak banyak terus nasinya dikit aja karena masih pagi. Oh coco crunch, ini nggak boleh terlewatkan. Sarapan wajib kalo di hotel. Udah cukup segini aja kalo lama-lama nanti malah jadi mukbang.

SW: Emang lumayan harus sabar sih kalo makan di sini. Dan menu yang dikasih tuh juga banyak. Aku pilih tiga macem. Salah satunya yang (lekker) Ovamaltine keju. Aromanya wangi banget! Can! Ini yang aku suka karena nggak terlalu garing dan ininya (tengahnya) lembek

Pada data ketiga disajikan kuliner khas Semarang. Ragam bahasa yang digunakan oleh SW yaitu ragam nonformal. Terdapat 3 kata yang tidak baku dan 5 tuturan khas SW yang digunakan. Selain itu juga disajikan 5 makanan atau jajanan khas Semarang.

Berdasarkan data di atas terlihat SW menjelaskan jajanan khas Semarang dengan ciri khas penutur. Hal tersebut dapat terlihat pada data [3.1], [3.3], [3.4], [3.5]. Pilihan kata yang digunakan penutur dalam menjelaskan makanan melalui kalimat yang persuasif dan informatif sehingga seolah-olah penyimak akan sama-sama merasakan.

\section{Tabel 4}

Hasil Analisis Bahasa dan Tuturan Data 4

\begin{tabular}{|c|c|}
\hline Aspek & Keterangan \\
\hline \multirow[t]{6}{*}{ Bahasa } & Ragam tidak baku: \\
\hline & Deket, ngeracik, pake, gitu, dikit, ama, nempel, seger, dihalusin, kalo \\
\hline & Ragam bakunya: \\
\hline & Dekat, meracik, pakai, begitu, sedikit, sama, menempel, segar, dihaluskan, kalua, \\
\hline & Kosa kata penamaan: \\
\hline & $\begin{array}{l}\text { Singkong tabur coklat keju, kopi aceh gayo, coto ceker, soto ranjau, soto sayap, soto madura, } \\
\text { soto kikil, koya, nasi goreng, sate ayam }\end{array}$ \\
\hline \multirow[t]{4}{*}{ Tuturan } & $\begin{array}{l}\text { 1) SW: Selamat makan! Ehm. aku kopi dulu deh. Enggak, aku mau singkong dulu. Ini } \\
\text { sinkongnya ada dua macem, coklat sama keju atau bisa juga yang ini, pake sambel roa. Aku } \\
\text { maunya coklat keju aja Ini kan ada susu, susunya ini buat kopi. Tapi ini kan kebanyakan } \\
\text { segini yah, jadi aku bisalah di sini dikit. Biar coklat ama kejunya nempel. }\end{array}$ \\
\hline & $\begin{array}{l}\text { 2) SW: Selamat makan! Meskipun namanya pak gendut, tapi namanya nggak gendut. Tapi ini } \\
\text { aku suka karena seger gitu lo! Can!! }\end{array}$ \\
\hline & $\begin{array}{l}\text { 3) SW: Setelah itu pake koya. Koya itu kerupuk udang yang dihalusin. Yang bisa bikin soto } \\
\text { makin gurih. Jadi bukan koya BT21 yah. Kalian jangan salfok. Koyanya yang banyak } \\
\text { karena enak sekali. Can! (Selain kerupuk udang, bawang putih juga dihalusin... jadilah } \\
\text { koya) }\end{array}$ \\
\hline & $\begin{array}{l}\text { 4) SW: Biasanya kan kalo nasi goreng dia nasinya kayak terpisah gitu kan. Kalo ini tuh } \\
\text { nasinya agak lembek. Tapi nggak yang terlalu basah. }\end{array}$ \\
\hline
\end{tabular}

Pada data 4 terdapat penggunaan ragam bahasa nonformal sebanyak 10 kata, kosakata penamaan sebanyak 9 makanan, dan 4 tuturan khas SW. Pada video kuliner kali ini SW menjelaskan jajanan khas Jakarta. Penggunaan kata seperti salfok [4.4] merupakan akronim serta tuturan khas anak-anak masa kini. Kata tersebut merupakan akronim dari salah fokus. Hal ini menunjukan bahwa SW menggunakan bahasa anak kekinian dengan tujuan agar para penyimak lebih mudah memahami. 


\section{Tabel 5}

Hasil Analisis Bahasa dan Tuturan Data 5

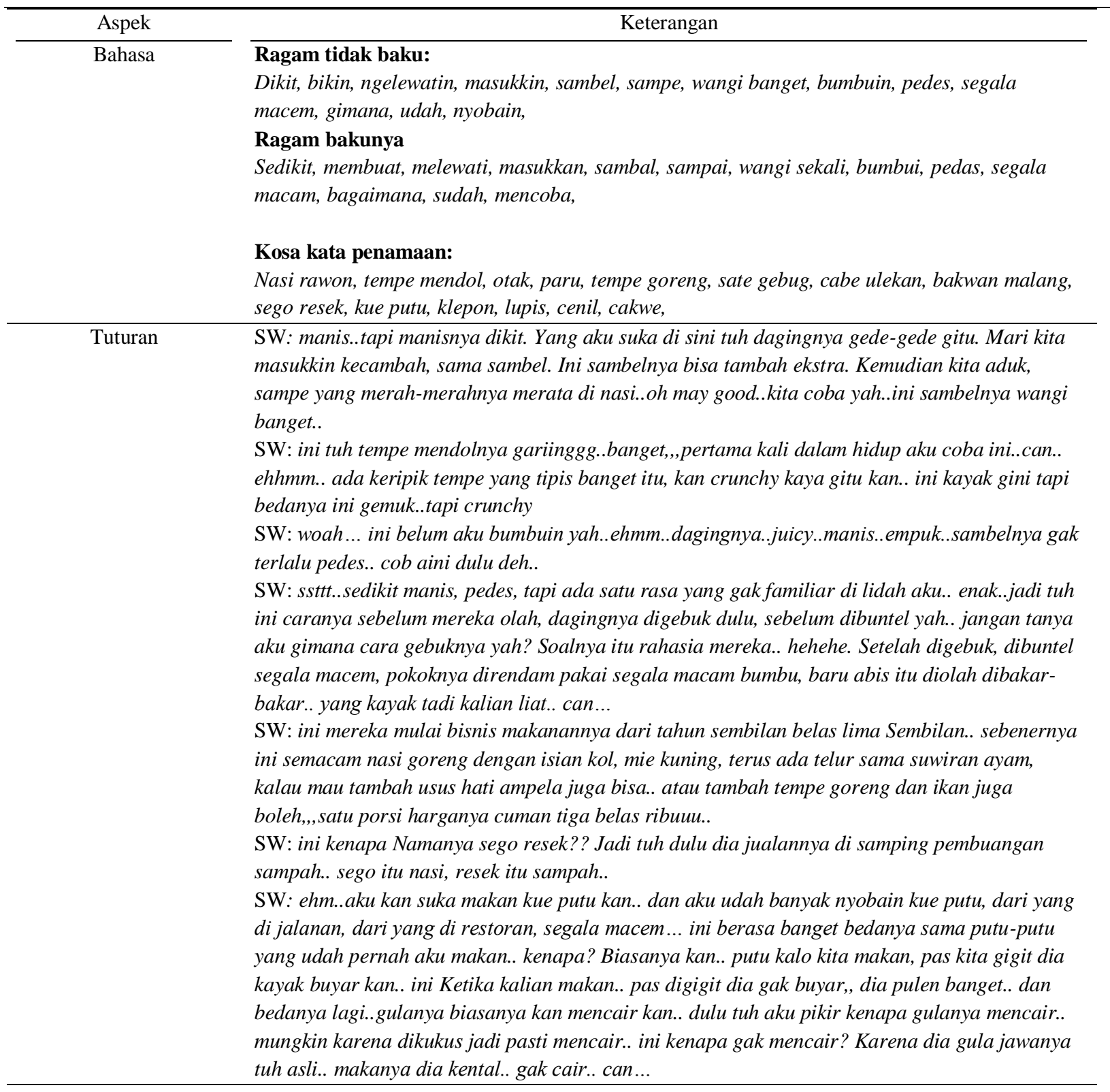

Pada data 5 video food vlogger membahas makanan khas Malang. Hasil analisis menunjukkan terdapat 13 kosakata tidak baku, 14 kosakata penamaan, dan 7 tuturan khas SW. Dalam video 5, terdapat tuturan SW yang menjelaskan tentang asal penamaan suatu kata menurut adat kebiasaan orang Malang. Hal tersebut dapat terlihat pada data [5.6]. SW memberikan informasi tentang asal kata sego resek. Tidak hanya itu, pada data [5.7] SW menjelaskan tentang perbandingan makanan khas Malang yaitu putu. Membandingkan mulai dari proses pembuatan sampai bentuk yang khas. 


\section{Tabel 6}

Hasil Analisis Bahasa dan Tuturan Data 6

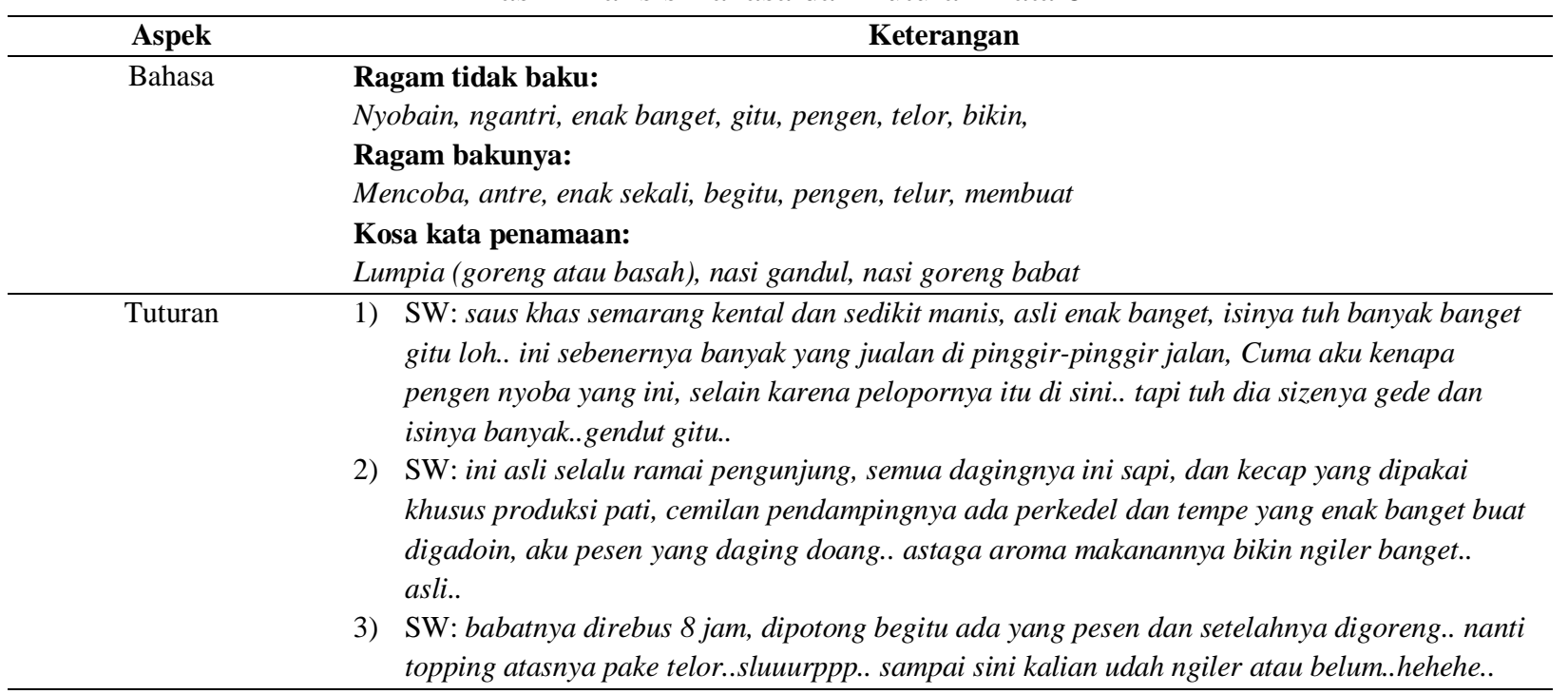

Dalam video 6 kali ini membahas kuliner khas Semarang. Hasil analisis menunjukkan terdapat 7 kosakata tidak baku, 3 penamaan makanan khas Semarang, dan 3 tuturan khas SW. Tuturan khusus SW dalam video 6 terlihat pada data [6.1], [6.2], [6.3]. SW menjelaskan dengan gaya khasnya tentang makanan lumpia dengan begitu persuasif sehingga memberikan daya tarik bagi penyimak.

\section{Tabel 7}

Hasil Analisis Bahasa dan Tuturan Data 7

\begin{tabular}{ll}
\hline Aspek & \multicolumn{1}{c}{ Keterangan } \\
\hline Bahasa & Kalo, liat, bikin, ginian, udah, ngantri, nyampe, samperin, \\
& Ragam bakunya: \\
& Kalau, lihat, membuat, begini, sudah, mengantre, sampai, datangi, \\
& Kosa kata penamaan: \\
& Wedang ronde, tengkleng, surabi, nasi liwet \\
& SW: ini pagi-pagi kalo lagi sakit perut makan yang ginian kayanya sembuh deh.. soalnya jahe.. \\
& kita belek ya.. can.. ini sebenernya bisa panas, bisa dingin, tapi aku pilih panas, soalnya kalo jahe \\
& enaknya panas.. ini sayang kalo airnya ga diminum.. cheersss.. \\
& SW: aku mulai dari tengkleng Bu Edi yang udah ada dari tahun 71, karena dalam waktu dua jam \\
& udah abiss.. jadi tuh lebih baik kalian datang lebih cepat buat ngantri, pas udah nyampe kalian ke \\
& pedagangnya untuk minta nomor antrean, nanti mereka akan panggil sesuai dengan urutan \\
& nomornya. Tinggal samperin mbaknya dan bilang kalian maunya apa.. \\
& SW: surabi ini sudah jadi favorit selama 4 generasi.. wow.. selain itu mereka juga jual berbagai \\
& macam cemilan, tapi aku udah pastilah mau beli surabi, untuk harganya..priiissss... kalian bisa \\
& catet sendiri ya.. \\
& SW: warung makan nasi liwet Yu Sani buka jam setengah 5 sore, ini aku datang persis di jam \\
& buka biar gak kena ngantri.ini isinya ada labu, suwiran ayam, dan teman-temannya.. dan yang \\
& paling menarik tampilan cabenya ini loh.. tetep ya fokusnya ke cabe.. hehehe \\
\hline
\end{tabular}

Video 7 membahas kuliner khas Solo. Hasil analisis data diperoleh terdapat 7 kosakata tidak baku, 4 kosakata penamaan, dan 4 tuturan khas SW. Tuturan khas SW tentang cara 
penjelasan suatu makanan khas tersaji pada data [7.1] mengenai wedang ronde. SW menjelaskan sambil menikmati wedang ronde dengan gaya khasnya. Meskipun menggunakan bahasa ragam nonformal tapi tetap dapat terpahami maksud dari yang sedang disampaikan kepada penyimak.

\section{Tabel 8}

Hasil Analisis Bahasa dan Tuturan Data 8

\begin{tabular}{ll}
\hline Aspek & \multicolumn{1}{c}{ Keterangan } \\
\hline Bahasa & Ragam tidak baku: \\
& Ragam bakunya: \\
& Mengunyah, sudah, ditambahkan, pedas, enak sekali, ramai, tetap \\
& Kosakata penamaan: \\
& Nasi kikil, perkedel, sambel bawang, serundeng, daun papaya, ikan teri goreng, ayam rica-rica, \\
& bandeng presto, sate buntel, tengkleng, tengkleng rica, pentol, \\
& SW: Ibu aku mau makan di sini. Nasi kikil yah bu. Sama perkedel. Kikilnya udah pedes sih. Tapi \\
& kalo kalian mau lebih pedes bisa ditambahin sambel bawangnya yang juga pedes. Jadi ini \\
& campuran kikil sama sambel bawang. Can!!! \\
& SW: Dagingnya tuh enak banget. Tadi pas aku ke sini driver grabnya bilang ini emang rame. Ini \\
& aku makan jam 09.50. Jadi belum rame. Suapan terakhir! Tadaaa! Nambah! \\
& Ini kalo kalian udah di kampus ISInya, ke sebelah sini di gang pertama masuk ke dalam. Setelah \\
& itu, nah begitu lurus teruskan ada kiri sama lurus. Ini kita tetep yang lurus. \\
\hline &
\end{tabular}

Pada tabel 8 video yang dianalisis berisi penjelasan tentang kuliner khas Solo. Berbeda halnya dengan video 7 meskipun di tempat yang sama yaitu Solo, makanan yang dideskripsikan berasal dari daerah dekat kampus ISI. Hasil analisis diperoleh 7 kosakata tidak baku, 12 kosakata penamaan, dan 3 tuturan khas SW. Dalam video $8 \mathrm{SW}$ menjelaskan dengan sangat persuasif dan informatif tentang nasi kikil dan perkedel. Dengan ciri khas gaya berbicaranya sangat memudahkan para penyimak untuk memahami yang dimaksud. Meski terdapat kos kata yang tidak baku dalam tuturan tersebut, tapi masih dalam tahap wajar.

Tabel 9

Hasil Analisis Bahasa dan Tuturan Data 9

\begin{tabular}{ll}
\hline Aspek & \multicolumn{1}{c}{ Keterangan } \\
\hline Bahasa & Emang, udah, dikecapin, sambelnya, bikin, telen, ngeracik, ngelihat, \\
& Ragam bakunya: \\
& Memang, sudah, diberi kecap, sambalnya, membuat, telan, meracik, melihat, \\
& Kosa kata penamaan: \\
& Gultik, gulai, lekker, piscok, es pudding, \\
\hline 1) & SW: Gultik kan emang udah enak yah. Terus ditambah sambelnya ini yang bikin makin enak \\
& banget. \\
2) & SW: Kita lanjut ke piring ke dua! Oh tidak... begitu tutupnya dibuka dan gulainya langsung di \\
& sendok ke piring, ini udah berhasil bikin kita telen lidah duluan tau nggak sih. Yang paling \\
& aku bagian ngeracik sendiri. Terserah mau seberapa banyak kecap dan sambelnya, bebas! \\
& Gratis! Bapaknya tuh nggak bakal marah. \\
3) & SW: Aku suka banget lekker yang dijual di sebrangnya gultik. Yang satu rasa harganya dua \\
& ribu, klo rasanya dimix gitu dua ribu lima ratus. Yang paling aku suka dari jaman sekolah tuh \\
& ngeliat abangnya klo lagi bikin lekker. Seru aja gitu kayak berasa ngeliat lukisan atau bikin \\
& tanah liat cuma ini bedanya kayak bikin kue. Iya nggak sih? \\
\hline
\end{tabular}


4) SW: Pada dasarnya kan aku emang penggemar berat piscok. Cuma yang di sini tuh enaknya juara sih. Aku paling suka sama tapenya dan di sini tuh piscoknya cepet abis. Oh... coklatnya royal banget. Duh jadi ngiler sendiri.

5) SW: Aku suka banget ini tapenya. Tapenya tuh manis gitu lo. Ini enak banget, parah. Hmm. Dari semua isiannya podeng gitu (pacar cina, alpukat, roti, tape, es krim, ketan hitam) yang aku nggak suka cuma ketan hitam.

Hasil analisis aspek berbahasa dan kebahasaan dalam video 9 diperoleh 8 kosakata tidak baku, 5 kosakata penamaan, dan 5 tuturan khas SW. Pada video 9 SW menjelaskan makanan khas Blok M. Seperti biasa dengan gayanya yang khas, SW menjelaskan gultik, gulai, lekker, piscok, es pudding dengan bahasa yang sangat persuasif. Hal tersebut dapat terlihat pada data [9.1], [9.2], [9.4], dan [9.5].

Tabel 10

Hasil Analisis Bahasa dan Tuturan Data 10

\begin{tabular}{ll}
\hline Aspek & \multicolumn{1}{c}{ Keterangan } \\
\hline Bahasa & Ragam tidak baku: \\
& Ngapain, pesen, nyobain, sediain, udah, temen, dapet, kecium \\
& Ragam bakunya: \\
Sedang apa, pesan, mencoba, menyediakan, sudah, teman, dapat, tercium, \\
Kosa kata penamaan: \\
oseng mercon, nasi campur lidah, bubur duren lekoh, jus asam jawa, kue kepo, cilok gajahan, \\
gudeg \\
1) SW: kata temen aku yang asli Jogja, harga di sini tergantung siapa yang beli, kalau bukan \\
orang Jogja harganya bakalan lebih mahal. Jadi yang ada di video ini harga yang aku dapet \\
yah,,, \\
2) SW: aku pesen nasi campur lidah yang isinya ada keripik kentang, lidah sapi sambel kutai, \\
satu porsi tiga puluh dua ribu rupiah.. aku juga pesen bubur duren lekoh yang remomended \\
banget..dia tuh ada dua size gitu, size kecil dan besar, dan ini size yang kecil. \\
3) SW: mau ibu..ini isinya ada lupis, cenil, dan semuanya Cuma lima ribu rupiah \\
4) SW: isinya itu ada isian daging sapi asli makanya rasanya agak beda dari yang lain. \\
Ciloknya itu ada dua macem, ada yang digoreng sama yang direbus. Dan untuk sambelnya \\
mereka tuh pake cabe rawit yang masih segar, trus pake bawang merah bawang putihnya \\
dihalusin sama rempah-rempah lainnya yang aku gak tau..hehe \\
5) SW: ini wangi nangkanya parah banget sih..kecium sampe luar..seriusan..ada krecek, ayam, \\
tempe bacem, telor, sama ati ampela.
\end{tabular}

Pada data 10 video food vlogger membahas makanan khas Malang. Hasil analisis menunjukkan terdapat 8 kosakata tidak baku, 6 kosakata penamaan, dan 5 tuturan khas SW. Dalam video 10, terdapat satu kebudayaan Jogja yang menjadi khas dibandingkan daerah lainnya. Hal tersebut ditunjukkan oleh data [10.1], budaya jual beli. Apabila bukan asli orang Jogja yang membeli maka harga akan cenderung lebih mahal. Selain itu juga pada data 10 terdapat tuturan SW pada saat menjelaskan makanan nasi campur, bubur duren lekoh, dan gudeg sangat persuasif dan informatif, yaitu pada data [10.2], [10.4], [10.5]. Sehingga memberikan kesan daya tarik bagi penyimak. 


\section{Tabel 11}

Hasil Analisis Bahasa dan Tuturan Data 11

\begin{tabular}{cl}
\hline Aspek & \multicolumn{1}{c}{ Keterangan } \\
\hline Bahasa & Ragam tidak baku: \\
& Ngeliat, rasain, udah, pake, \\
& Ragam bakunya: \\
& Melihat, rasakan, sudah, pakai, \\
& Kosa kata penamaan: \\
& Nasi jagung, bakwan jagung, cilok campur pangsit goreng, keripik tempe, orem-orem, rujak cingur, \\
& nasi pecel, bakwan malang, bakso malang, goreng mekar, tahu isi udang, jamur es, bakso urat, \\
& godeng udang, sayur, sempol crispy, tahu bakso, risoles mayo \\
\hline 1) & SW: Aku pesan cumi, ikan bandeng pedas, sama nasi jagung. Selamat makan! Ini sebenarnya \\
& menu andalan itu salah satunya ada yang namanya ikan kakap, (sayur ikan tuna pedas, sayur \\
& ikan nila pedas. sayur udang pedas) tapi lagi nggak ada. Jadi aku pesan yang ikan bandeng. \\
& Seperti biasa, ininya... Wah! Dia tuh ada serundeng gitu! Can ... \\
2) & SW: Ini tuh (sempol) pake tepung kanji sama potongan ayam sama tepung terigu. Itu sempol \\
& pada umumnya kan? Bedanya kalo yang ini dia pake tepung roti. Jadi dia tuh lebih crispy gitu \\
& makannya. Yummy... perjalaan mutar-mutar terbayang dengan ini. Can!! Kayaknya mau gua \\
& bawa pulang buat di hotel deh! Bapak... aku, aku boleh tiga lagi nggak? \\
\hline
\end{tabular}

Analisis video 11 diperoleh hasil yaitu terdapat 4 kosa kata tidak baku, 18 kosa kata penamaan, dan 2 tuturan khas SW. Pada video 11 wisata kuliner yang disajikan adalah jajanan khas Malang. Pada data 11 tuturan persuasif terdapat pada data [11.1], [11.2]. Dalam video tersebut SW mencoba menjelaskan dan menginformasikan kepada penyimak tentang makanan khas Malang yaitu ikan bandeng dan sempol. Melalui pilihan kata yang digunakan SW sehingga menghasilkan tuturan yang bisa menjadi daya tarik bagi penyimak, khususnya pecinta kuliner.

Tabel 12

Hasil Analisis Bahasa dan Tuturan Data 12

\begin{tabular}{ll}
\hline Aspek & Ragam tidak baku: \\
& Pengen, pedes, datengin, sambel, kalo, \\
& Ragam bakunya: \\
& Ingin, pedas, datangi, sambal, kalau, \\
& Kosa kata penamaan: \\
& Gulai kambing, \\
\hline Tuturan & 1) SW: mari kita coba kambingnya..can.. wow cabenya pedes banget \\
& 2) SW: seriusan ini enak banget parahhh..asli..asli..di sini tuh gak ada sambel, rasa pedesnya \\
& dari labu..jadi kalo mau pedes banget, labunya bakal dikasi banyak..wah..gini ceritanya aku \\
& nambah sih..can.
\end{tabular}

Pada video 12 dapat diperoleh hasil analisis yaitu terdapat 5 kosakata tidak baku, 1 kosakata penamaan, dan 2 tuturan khas SW. Kuliner yang disajikan dalam video 12 yaitu makanan khas Semarang.

\section{Tabel 13}

Hasil Analisis Bahasa dan Tuturan Data 13

\begin{tabular}{cl}
\hline Aspek & Keterangan \\
Bahasa & Ragam tidak baku: \\
& Kesel, nanya, bulet, abis itu, anget-anget, macem-macem, ngeracik, pake, sambel \\
& Ragam bakunya: \\
\hline
\end{tabular}


kesal, tanya, bulat, setelah itu, hangat-hangat, macam-macam, meracik, pakai, sambal Kosa kata penamaan:

Tuturan

Selat Solo, selat lidah, selat bestik, gempol pleret, mie thoprak, mie ayam tugu lilin, semur,

1) SW: selat bestik! Terus tadi kan aku nanya kan, selat bestik tuh apaan? Ternyata itu potongan daging sapi. Tapi katanya lebih banyak dipesan sama orang tuh selat lidah. Can!

2) SW: Wah aku suka kuahnya. Agak-agak kayak semur yah. Isinya ada kentang, timun (bengkuang) yang dipotong kayak kentang goreng (telor, lidah sapi). Dan ini yang paling aku suka banget. Ini sahabat aku, bawang merah. Kenapa aku suka bawang merah? Soalnya aku bawang putih.

3) SW: Hm.. sama kayak cendol yah. Ini tuh sebenarnya beras. Jadi untuk bisa bulet kayak gini tuh berasnya tuh dikeringin sama ditumbuk-tumbuk. Abis itu baru kayak bisa dibentuk kayak gini. Ini harus beras yang kualitasnya bagus sih. Can!

4) SW: Ini tuh dagingnya direbus selama berjam-jam. Jadi rasa kuahnya tuh kuat banget. Satu mangkok isi surga dunia. Asli! Ini harus dimakan pas lagi anget-anget gitu. Ini aku mau coba kuah yang original tanpa aku kasih bumbu macem-macem. Can! Astaga, ini rempahnya berasa banget sih asli. Dari kuahnya aja tuh bisa berasa dagingnya sama kayak ada bawang putih dan ladanya. Ini aku mau ngeracik. Tadi bapaknya bilang biasanya kalo orang Solo itu pake kerupuk ini. Ini kerupuk apa sih namanya? Aku pake ini aja deh. Jadi ini diancurin kecilkecil terus diaduk. Aku mau pake sambel juga, tiga sendok cukup. Ok, lagi program KB sambel. Can!

Pada video 13 diperoleh data hasil analisis yaitu terdapat 9 kosakata tidak baku, 7 kosakata penamaan, dan 4 tuturan khas SW. dalam video ini kuliner yang dideskripsikan adalah makanan khas Solo. Dalam video $13 \mathrm{SW}$ melalui tuturan khasnya mendeskripsikan makanan khas Solo yaitu selat Solo, selat lidah, selat bestik, gempol pleret, mie thoprak, mie ayam tugu lilin, semur. Dengan pilihan kata yang mudah dipahami dapat memberikan kesan yang persuasif dan informatif, sehingga orang yang menyimak video tersebut akan tertarik untuk mencobanya.

Tabel 14

Hasil Analisis Bahasa dan Tuturan Data 14

\begin{tabular}{ll}
\hline Aspek & Ragam tidak baku: \\
\hline Bahasa & Malem-malem, segala macem, anget, ngeracik, sambel, udah, bikin, pengen, nelen \\
& Ragam bakunya: \\
& Malam-malam, segala macam, hangat, meracik, sambal, sudah, membuat, ingin, menelan \\
& Kosa kata penamaan: \\
& soto segernya mbak ronggeng, tempe mendoan, gudeg ceker \\
& 1) $\quad$ SW: ini di meja sini ada.. taraaa.. ada tempe dan ada tahu.. kayanya aku pilih tempe deh.. \\
& kemudian ada sambelnya... gila sambelnya biji semuaa.. \\
& 2) $\quad$ SW: ini aku pesen setengah nasi, udah pasti ada sayur nangkanya.. dan ini yang bikin aku \\
& ngiler, krecek.. aduuh.. liat warna kreceknya jadi kaya pengen nelen semuanya.. tau gak \\
& sih..hehehe.. dan yang terakhir udah pastilah ya harus ada cekernya.. \\
\hline
\end{tabular}

Pada video 14 hasil analisis diperoleh yaitu terdapat 9 kosakata tidak baku, 3 kosakata penamaan, dan 2 tuturan khas SW. dalam video tersebut kuliner yang dibahas yaitu makanan khas Solo. Video ini merupakan kelanjutan dari video sebelumnya. Tuturan khas SW terdapat pada data [14.1] dan [14.2]. Dalam video tersebut SW mendeskripsikan makanan khas Solo yaitu soto mbak ronggeng, tempe mendoan, dan gudeg ceker. Pilihan kata yang digunakan SW memberikan kesan yang menarik dan persuasif. Hal ini terlihat pada saat SW menjelaskan tentang sambal pada data 
[14.1]. Dia mengatakan "gila sambelnya biji semuaa..". penggunaan kata "gila" di sana bukan berarti "gangguan jiwa" melainkan "tidak biasa".

Tabel 15

Hasil Analisis Bahasa dan Tuturan Data 14

\begin{tabular}{ll}
\hline Aspek & \multicolumn{1}{c}{ Keterangan } \\
\hline Bahasa & Segala macem, nangkep, emang, gimana, nyobain, ngolahnya \\
& Ragam bakunya: \\
& Segala macam, tangkap, memang, bagaimana, mencoba, mengolahnya \\
Kosa kata penamaan: & Betutu peda, betutu goreng, sambal matah, plecing, ikan bakar kresi, udang bakar super \\
& madu, bandeng woku, bungas jagung \\
1) SW: aku mau nyobain yang betutu pedesnya dulu deh...can.. wuahhh..pedes..pedes... \\
2) SW: jadi ini ayam atau bebek betutu ya diungkep sama bumbu-bumbu dapur ada \\
jahe, lengkuas, kunyit, kencur, daun jeruk..sama yang paling terpenting ada rawit... \\
3) SW: ehmmm..dagingnya lembut. Ini kan ikan kresi yah, sebenernya ikan kresi ini \\
mudah didapat, tapi ga terlalu banyak yang suka soalnya tuh banyak duri sama \\
banyak sisik. Tapi sebenernya tergantung sih gimana cara ngolahnya. Ini diolah \\
dengan baik. \\
4) SW: pada dasarnya emang aku suka banget sama sambal matah. Ehm..ini dia \\
bawang putihnya gariiinggg..banget sama kering...jadi kalo kalian ke sini katanya sih \\
lebih baik emang telepon dulu gitu..Tapi aku tadi gak telepon dulu sih.. aku lagsung \\
datang ke sini. Tapi aku tadi datang ke sininya agak lebih pagi supaya dapat tempat \\
duduk. Soalnya di sini cuman ada Sembilan meja..can... \\
5) SW: karena di sini spesialisnya emang udang gitu yah, jadi kita harus coba udangnya \\
dulu..aduh..ini menggoda nih..wanginya...hahahaha...can... \\
\hline
\end{tabular}

Video 15 merupakan data terakhir yang dianalisis. Hasil analisis diperoleh 6 kosakata tidak baku, 8 kosakata penamaan, dan 5 tuturan khas SW. Dalam video ini kuliner yang dibahas yaitu makanan khas Kuta. Tuturan khas SW yang dianalisis terdapat pada data [15.2], [15.3], dan [15.4]. Dalam video tersebut SW mendeskripsikan dan menjelaskan cara pengolahan ayam betutu dengan menggunakan bahasa yang lebih persuasif. Selain itu pilihan kata yang digunakan memberikan kesan yang menarik. Hal tersebut terlihat pada data "menggoda nih..wanginya...hahahaha...can...". Penggunaan kata "menggoda", menunjukkan bahwa makanan tersebut sangat lezat dan menggugah selera.

Langkah berikutnya setelah analisis dan pembahasan data yang tersaji dalam 15 video food vlogger Ria SW adalah penyusunan bahan ajar BIPA. Adapun simpulan hasil analisis video diperoleh sebagai berikut:

Tabel 16

Hasil Analisis Video

\begin{tabular}{llc}
\hline No & \multicolumn{1}{c}{ Aspek Analisis } & Jumlah Data \\
\hline 1 & Kebahasaan: & \\
& Kosa kata tidak baku & 102 \\
& Kosa kata penamaan & 117 \\
2 & Tuturan & 68 \\
\hline
\end{tabular}


Berdasarkan data tersebut selanjutnya adalah tahap penyusunan bahan ajar. Bahan ajar yang disusun disesuaikan dengan rencana pembelajaran BIPA. Rencana tersebut tertuang dalam silabus BIPA. Adapun kompetensi yang harus diajarkan sesuai dengan silabus adalah "Матри memahami dan menggunakan ungkapan sehari-hari untuk pemenuhan kebutuhan yang konkret, seperti bertanya arah dan lokasi dan bercerita tentang aktivitas harian."

Bahan ajar yang disusun berisi dua kompetensi yang harus diajarkan, yaitu pertama pemahaman tata bahasa, dan kedua pemahaman kosakata. Untuk materi ajar kedua kompetensi tersebut diambil dari hasil analisis. Tersedia 102 kosakata baku dan tidak baku, serta kosakata penamaan sebanyak 117. Sedangkan untuk contoh kalimat digunakan dari tuturan yang telah diidentifikasi dari video food vlogger Ria SW.

Bahan ajar yang telah disusun selanjutnya diujicobakan kelayakannya kepada para pengajar BIPA yang ada di Kota Bandung sebagai sampel penelitiannya. Adapun indikator penilaian kelayakan tersebut meliputi: 1) kesesuaian topik dengan bahan ajar; 2) langkah pembelajaran; 3) evaluasi pembelajaran. Hasil pengujian bahan ajar terlihat pada tabel berikut.

Tabel 16

\begin{tabular}{llcccc}
\multicolumn{4}{c}{ Pemanfaatan Youtube sebagai Bahan Ajar BIPA } \\
\hline \multirow{2}{*}{ No } & Sub Indikator & \multicolumn{4}{c}{ Presentase Alternatif } \\
& & Jawaban \\
& & S & TS & STS \\
\hline 1 & Kesesuaian topik dengan bahan ajar & $80 \%$ & $20 \%$ & 0 & 0 \\
2 & Langkah pembelajaran & $60 \%$ & $40 \%$ & 0 & 0 \\
3 & Evaluasi pembelajaran & $80 \%$ & $20 \%$ & 0 & 0 \\
\hline
\end{tabular}

Berdasarkan data di atas dapat dilihat bahwa tanggapan responden mengenai pemanfaatan youtube sebagai bahan ajar berbicara untuk BIPA sangat setuju. Youtube merupakan media sosial yang dapat digunakan oleh mahasiswa BIPA sebagai media pembelajaran berbicara. Mahasiswa dapat berlatih berbicara dari video yang telah disimak terlebih dahulu. Belajar memahami kosakata yang digunakan para youtuber dapat menambah perbendaharaan kosakata. Kebudayaan daerah yang dipelajari dari food vlogger dapat dijadikan bahan pembelajaran. Mengenal budaya sama halnya dengan mempelajari Bahasa.

Hasil penelitian ini menunjukkan bahwa bahan ajar yang diambil dari hasil analisis bahasa dan kebahasaan dari video food vlogger Ria SW efektif digunakan. Mahasiswa BIPA antusias mengambil topik tentang kuliner dan kebudayaan daerah dalam pembelajaran berbicara.

\section{Simpulan}

Berdasarkan hasil analisi yang dtelah dilakukan melalui penelitian ini, dapat ditarik kesimpulan sebagai berikut:

1) Hasil analisis bahasa dan kebahasaan dalam 15 video food vlogger Ria SW diperoleh terdapat kosakata tidak baku dalam tuturan sebanyak 102. Hal tersebut biasa terjadi dalam tuturan langsung. Penutur beranggapan bahwa kosakata tersebut lebih menunjukkan keragaman bahasa santai. Sengaja oleh peneliti dijadikan fokus penelitian harapannya mahasiswa BIPA 
memahami kosakata ragam formal dan tidak formal, serta ragam baku dan tidak baku yang nantinya akan digunakan dalam kegiatan berbicara. Data berikutnya diperoleh sebanyak 117 kosakata penamaan pada suatu makanan yang sedang di-review oleh SW. Konsep penamaan tersebut terdapat di dalamnya karena pengaruh dari budaya daerah setempat. Hasil analisis ini diharapkan dapat dijadikan sebagai topik pembelajaran berbicara untuk mahasiswa BIPA yang sudah disediakan pada bahan ajar.

2) Hasil pengujian bahan kepada para pengajar BIPA menunjukkan hasil bahwa bahan ajar tersebut efektif untuk pembelajaran BIPA. Hal ini dapat dilihat dari hasil penyebaran angket diperoleh rata-rata $75 \%$ jawaban sangat setuju.

\section{Saran}

Kami menyadari bahwa hasil penelitian masih perlu adanya pengujian yang lebih mendalam terkait dengan pemanfaatan youtube untuk dijadikan bahan ajar. Harapannya dipenelitian berikutnya hal ini bisa dijadikan sebagai penelitian lanjutan.

Adapun saran yang dapat diberikan dari penelitia adalah: 1) Bagi pengajar BIPA, yaitu hendaknya selalu berinovasi dalam pembelajaran terutama yang berkaitan dengan pemanfaatan media pembelajaran. Youtube merupakan media yang efektif untuk membantu mahasiswa BIPA dalam belajar berbicara untuk kebutuhan interaksi; 2) Bagi peneliti yang akan datang, yaitu perlu adanya perbandingan tuturan dari beberapa youtuber sebagai studi perbandingan juga diperluar jumlah sampel penelitiannya.

\section{Daftar Pustaka}

Adji, M. 2018. "Budaya dalam Pengajaran BIPA: Respons Orang Asing terhadap Budaya Sunda dalam Hubungan Lintas Budaya”. Metahumaniora, 8(2). Tersedia pada :

http://jurnal.unpad.ac.id/metahumaniora/article/view/20703 diakses pada : [16 Agustus 2019]

Arikunto, Suharsimi. 2006. Metodologi Penelitian. Yogyakarta: Bina Aksara

Budiargo, Dian. 2015. Berkomunikasi Ala Net Generation. Jakarta: PT Elex media

Komputindo.

Chaer, A., 2009. Psikolinguistik: Kajian Teoretik. Ke2 penyunt. Jakarta: Rineka Cipta.

David, Eribka Ruthellia dkk. 2017. "Pengaruh Konten Vlog dalam Youtube terhadap Pembentukan Sikap Mahasiswa Ilmu Komunikasi Fakultas Ilmu Sosial dan Politik Universitas Sam Ratulangi”. E-Journal Acta Diurna. Vol. 6 (No.1). Tersedia:

https://ejournal.unsrat.ac.id/index.php/actadiurna/article/view/1549/15020 diakses pada

[19 Juni 2018].

Mujianto, H., 2019. Jurnal Komunikasi Universitas Garut: Hasil Pemikiran dan Penelitian.

[Online] Available at: https://journal.uniga.ac.id/index.php/JK/issue/view/108 [Diakses 18 Agustus 2020 2020].

Siroj, M. 2015. "Pengembangan Model Integratif Bahan Ajar Bahasa Indonesia Ranah Sosial Budaya Berbasis ICT Bagi Penutur Asing Tingkat Menengah". Jurnal Pendidikan Bahasa
Dan
Sastra
Indonesia,
$4(2)$.
Tersedia
pada 
https://journal.unnes.ac.id/sju/index.php/jpbsi/article/view/11305 diakses pada [16 Agustus 2019]

Sugiyono. 2013. Metode Penelitian Kuantitatif, Kualitatif, dan R\&D. Bandung: Alfabeta

Tarigan, H. G. 2008. Menulis sebagai keterampilan berbahasa. Bandung: Angkasa.

Widia, Ida. 2016. "Bahasa Indonesia bagi Penutur Asing”. Senarai Bahan Ajar Pelatihan BIPA. Bandung: Rizqi Press 